\title{
МЕМУАРИ В. ГАЛАНА В ЯКОСТІ ДЖЕРЕЛА 3 ІСТОРІЇ ГАЛИЦЬКОЇ АРМІЇ
}

Анотація: Стаття присвячена аналізу спогадів Володимира Галана (1893-1978) в якості джерела з історії Галицької армії 1918-1920 рр., ї̈ участі у визвольній боротьбі та причинах невдач. Увага звертається на особистісний контекст формування мемуарних свідчень, з'ясовується ступінь їх об'єктивності, важливість наведеного фактичного матеріалу, корисність цієї інформації для відображення державотворчих процесів доби Української революиії.

Наголошено, що активне залучення спогадів сприятиме формуванню доволі обєєтивної картини перебігу історичних подій, активізуватиме вивчення державотворчих процесів початку ХХ ст. вітчизняною історіографією.

Ключові слова: мемуари, визвольна боротьба, державотворення, ЗУНР, Галищька армія, Українська революиіл 1917-1921 рр.

Характерною особливістю мемуарів, присвячених національно-визвольній боротьбі 19181919 рр. у Західній Україні, є велика кількість спогадів колишніх військовослужбовців рядових та офіцерів Галицької армії (ГА), які в умовах постійного збройного конфлікту 3 Польщею відігравали значно більшу роль у політичному житті, аніж військові керівники УНР. Окрему, досить важливу частину цієї мемуарної літератури становлять спогади військових, які боролися за українську державність по обидва береги Збручу. До них можна віднести мемуари С. Шухевича - п'ять томів «Споминів з Українсько-Галицької Армії ${ }^{\text {, }}$ спогади керівників збройних сил М. Тарнавського ${ }^{2}$, А. Кравса ${ }^{3}$, М. Омеляновича-Павленка ${ }^{4}$.

Не менш важливими для об'єктивного висвітлення подій, пов'язаних зі збройною боротьбою за ЗУНР, є спогади рядових бійців і старшин, які безпосередньо брали участь у військових операціях. Ці мемуаристи хоч і не володіли всім тим масивом стратегічної інформації, що належала їх керівникам, проте саме вони надають оцінки діям своїх командирів і політиків, що відповідали за успіхи та невдачі української армії. Мемуари цієї групи часто містять таку інформацію, яку важко знайти навіть в офіційних документах склад того чи іншого підрозділу, безпосередньо поставлені перед ним бойові завдання,

\footnotetext{
* Пархоменко Владислав Анатолійович - доктор історичних наук, доцент кафедри історії Миколаївського національного університету імені В.О. Сухомлинського (Миколаїв, Україна); ORCID: https://orcid.org/0000-0003-0911-2941; e-mail: vlad10031974@gmail.com

${ }^{1}$ Шухевич С. Спомини з Українсько-Галицької Армії (1919-1920): У 5 ч. Львів: Червона Калина, 1929. Ч. 1. 176 с.; Ч. 2.176 с.; Ч. 3.162 с.; Ч. 4.164 с.; Ч. 5.147 c.

${ }^{2}$ Тарнавський М. Спогади. Львів: Вечірня година, 1992. 128 с.

${ }^{3}$ Кравс А. За українську справу. Спомини про 3-й корпус УГА після переходу за Збруч. Львів: Червона Калина, 1937. 99 c.

${ }^{4}$ Омелянович-Павленко М.В. Спогади командарма (1917-1920). Київ: Темпора, 2007. 608 с.
} 
реакція воїнів на різні політичні події, фронтовий побут. Ці та інші моменти знайшли своє відображення у спогадах Д. Кренжаловського ${ }^{5}$, О. Кузьми ${ }^{6}$, Н. Іванини ${ }^{7}$ та багатьох інших. До цієї групи мемуарів належать також і спогади Володимира Галана «Батарея смерті», що побачили світ у США в 1968 p. ${ }^{8}$

На відміну від інших мемуаристів, спогадам В. Галана науковцями не приділено належної уваги. Виняток становить публікація львівських дослідників, присвячених історії артилерії ГА ${ }^{9}$. Зокрема, посилаючись на спогади В. Галана, авторами детально описано участь артилерійських підрозділів у визволенні Тернополя у червні 1919 р. від поляків ${ }^{10}$.

Проте, військові мемуари В.Галана не стали темою окремого дослідження, що й обумовило написання даної статті. Мета публікації: проаналізувавши спогади В. Галана, виявити їх інформаційну складову в якості джерела з історії Галицької армії 1918-1920 рр. Вивчення спогадів доби визвольної боротьби 1917-1921 рр., є безумовно актуальним, адже сприятиме формуванню та корегуванню білыш виразного образу минулого у сучасній історичній свідомості.

У передмові до книги, розповідаючи про історію їі написання й автора, відомий український громадський діяч I. Кедрин, у квітні 1968 р. писав: «Молодий вояк українець, спершу в австрійській, потім в українській арміях взяв собі за звичай - писати щоденник. Записував самі факти: де був, в якій служив частині, які були його зверхники і товариші, як проминав кожний день. Лише зрідка прикрашував ті факти своїми враженнями та давав волю своїм почуванням. За кілька років війни 3 первісного нотатника розрослась чимала книжечка. Зберігав її всю війну і вивіз з собою за море, в Америку» ${ }^{11}$. Оцінюючи світоглядну позицію мемуариста, І. Кедрин далі зауважив: «вся ця його книжка, пронизана соборницьким світоглядом, для якого існує тільки одна Україна, одна українська визвольна справа» ${ }^{12}$.

Свої спогади В. Галан (1893-1978) назвав «Батарея смерті», саме таку назву одержав його підрозділ під час важких боїв за Львів у листопаді 1918 р. Крізь призму бойової історії фактично однієї батареї, мемуарист передає читачам власне бачення й оцінку подій визвольної боротьби за українську державність у 1918-1920 рр.

Народився В. Галан у 1893 р. у м. Глиняни на Галичині. Свою розповідь про участь у національному русі, мемуарист розпочинає з гуртка «Пласт», заснованого у 1911 р. при Золочівській гімназії. Саме В.Галан став головою цього гуртка. Наступного року 30 пластунів з різних гімназій взяли участь у змаганнях і сходженню на Говерлу ${ }^{13}$. В групі

\footnotetext{
${ }_{5}^{5}$ Кренжаловський Д. Львів в українських руках (1-21.XI 1918). Украӥнські мемуари. Кам'янець: Стрілець, 1919. $53 \mathrm{c}$.

${ }^{6}$ Кузьма О. Листопадові дні 1918 р. Львів: Накладом автора, 1931. 464 с.

${ }^{7}$ Іванина Н. Залізні роки. Спомини 1914-1922. Львів: Вид. І. Тиктора, 1937. 132 с.

${ }^{8}$ Галан В. Батарея смерті. Джерсі-Сіті: Червона Калина, 1968. 240 с.

${ }^{9}$ Ткачук П., Кривизюк Л. Бойові дії артилерійських полків Галицької армії на фронтах польсько-української та більшовицько-української воєн // Україна: культурна спадщина, національна свідомість, державність: Зб. наук. пр. Львів: Інститут українознавства ім. І. Крип'якевича НАН України, 2012. Вип. 21. С. 760-775.

${ }^{10}$ Ibid. C. 771.

${ }^{11}$ Кедрин I. Вояк-громадянин та його книжка // Галан В. Батарея смерті. Джерсі-Сіті: Червона Калина, 1968.

C. 5-7.

${ }^{12}$ Ibid. C. 6.

${ }^{13}$ Галан В. Вказ.праця. С. 17.
} 
пластунів була й легендарна О. Степанів, майбутня хорунжа Січових стрільців, теж авторка спогадів про ті буремні роки.

3 початком Першої світової війни, В. Галан закінчує артилерійську школу, і як лейтенант 31 січня 1916 р. став командиром гірської батареї на Італійському фронті в Альпах, де велася позиційна війна. Наприкінці травня 1916 р. над розташуванням батареї італійські аероплани замість бомб розкидали листівки. Примітно, що вони були українською мовою, адже знали, що позиції займають галичани. У листівках був заклик кидати фронт і ставати на захист своєї Галичини, бо їй загрожував російський наступ ${ }^{14}$. Дійсно, російський Південно-Західний фронт розпочав тоді наступальну операцію «Брусиловський прорив».

Незабаром артилерійську частину В. Галана перекинуто до Галичини. Проте, 10 червня 1916 р. автор спогадів і його командир полковник Шлезінгер, обидва поранені, потрапили до полону. На підводі під конвоєм кубанського козака їх повезли в тил. Тут автор спогадів відзначив, як у українців, що опинилися в арміях ворогуючих імперій, пробуджувалась, хоча б і на побутовому рівні, національна свідомість. «Не знаю чому пригадалась мені тоді, в тій сумній хвилині, пісня кубанців «Засвистали козаченьки» і я у гарячці почав муркотати їі під носом. Козак підїхав конем до воза і здивовано спитав:

- Пан, а ти одкудова?

- Я українець з Галичини - відповів я.

- Как же ето - австрієць, офіцер, українець?

На його обличчі враз із здивуванням з'явилась радісна усмішка. I, не чекаючи на мою відповідь, він спитав чистою українською мовою:

- А ви що небудь їли сьогодні?

- Нi, - відповів я. Козак кудись почвалав i, за хвилину вернувшись, передав мені великий кусень хліба і сала» ${ }^{15}$.

Полонені потрапили спочатку до табору в Дарниці біля Києва, де вже було чимало українців з різних австрійських полків. Потім партію полонених у 300 осіб відправлено до містечка Болхів, приблизно за 70 км від Орла. Тут знову українці заявили про свою національну приналежність і одержали несподівану «підтримку». Російський прапорщик за списком перевірив усіх полонених: чехів, поляків та ін., але «до загальної суми забракло йому ще 21 особи, і він запитав:

- А іщо какіє національності здєсь?

Ми піднесли руки - акуратно 21.

- Какой національності? - запитав він.

- Українці!

В ту мить підвівся 3-за стола старий вусатий полковник, військовий командант округи, і заявив на повний голос:

- Гаспада, я тоже малорос!» ${ }^{16}$.

Як згадував мемуарист, це визнання полковника викликало велике здивування серед решти полонених, адже офіцер російської армії «признається до нас, як брат по крові, бо ж

\footnotetext{
${ }^{14}$ Ibid. C. 20.

${ }^{15}$ Ibid. C. 22.

${ }^{16}$ Ibid. C. 24.
} 
вони були переконані, що українство - це вигадка» ${ }^{17}$.

На початку 1917 р. до табору дійшли звістки, про появу в Києві Української Центральної Ради. Українці-полонені постійно зверталися до Ради з проханням допомогти звільнитися 3 полону. «Врешті одержали листа від самого проф. М. Грушевського, в якому він писав, що єдина поміч, яку може нам дати, це вислати трохи грошей, які саме одержав від американських українців. Він радив нам переодягтися в російські уніформи і втікати до Орла, де нам допоможуть старшини зукраїнізованої бригади» ${ }^{18}$. Частина полонених дослухалася до цієї поради. Група з чотирьох осіб, серед яких був і В. Галан, організувала втечу. Знову проявилася солідарність з українцями-наддніпрянцями. Допоміг полоненим вартовий українець. Він «радів, як дитина, коли ми читали йому вісті з Украіни. Цей вартовий купив нам військові російські шинелі та шапки і найняв людину з саньми, щоб довезла нас до Орла» ${ }^{19}$.

Подорож виявилася довгою: з Орла добралися до Гадяча, потім до Вінниці. Але місто вже здобули більшовики. Втікачам не було іншого виходу, як з масою австрійських полонених вертатися на батьківщину. У містечку Підволочиськ вони зустрілися 3 німецькою кіннотою. Командир ескадрону, молодий лейтенант, зустрів їх з військовими почестями і надав автомобіль. Порівнюючи ситуацію в Галичині, i ту, яка була в підконтрольній більшовиками Україні, мемуарист відзначив: «після двох місяців скитання по опанованій анархією країні ми опинилися наче в новому світі 3 непорушеними людськими вартостями, військовою дисципліною та відповідальністю влади» ${ }^{20}$.

Після відпустки і нової військової перепідготовки, 1 листопада 1918 р. В. Галан мав знову відїхати на Італійський фронт. Проте, події на Галичині, що увійшли в історію під назвою «Листопадового зриву», змінили долю автора спогадів. Вже 1 листопада 1918 р. станція Задвір'я, де перебував В. Галан, зайнята українським військом із Золочівського гарнізону. «Мені доручено перебрати владу в Глинянах. Підвід не було і над вечір я вирушив пішки до Глинян, де зараз же скликав збори всіх Січовиків та військових, які перебували там на відпустці 3 австрійської армії» ${ }^{21}$. Імпровізований український загін, без будь якого опору, розброїв місцевих жандармів, захопивши зброю, серед якої були кулемети.

Наприкінці 1918 р. В. Галан вирішив їхати на Львівський фронт до групи «Схід», штаб якої перебував у Куровичах. Як відзначив мемуарист: «кінець грудня 1918-го і січень 1919го року - це був властиво початок організації регулярної Української Галицької Армії 3 трьох військових груп - Північ, Схід і Південь. Постійного фронту ще не було» ${ }^{22}$. Групу «Схід» перетворено на 4-ту Золочівську бригаду, яка займала найбільшу ділянку Львівського фронту - від Брюхович до Винники. До цієї бригади включено 4-й гарматний полк у складі восьми батерій. Наприкінці лютого 1919 р. В. Галан призначений командиром п'ятої батареї 4-го гарматного полку. у мемуарах він відзначив, як це сталося. Коли

\footnotetext{
${ }^{17}$ Ibid. C. 24.

${ }^{18}$ Ibid. C. 25.

${ }^{19}$ Ibid. C. 26.

${ }^{20}$ Ibid. C. 29.

${ }^{21}$ Ibid. C. 32.

${ }^{22}$ Ibid. C. 34.
} 
надійшов наказ вночі відкрити вогонь, його виконали всі батареї, крім п'ятої. «Наступного дня сот.[ник] Лясковський вибрався до тієї батерії і на запит, чому вона не виконала наказу, одержав від хор.[унжого] Ліницького таку відповідь: "Вночі батерія не може стріляти, і я не давав наказу, бо його й так не виконали б”. Не було іншого виходу, як дати батерії іншого команданта» $»^{23}$, ним і став В. Галан.

У квітні розпочалися активні бої за Львів. 15 квітня назавжди запам'яталося мемуаристу - важка артилерійська дуель, батарею постійно бомбардувала польська авіація. «Батарея смерті», так її стали називати після цього бою, за день випустила 2 тисячі набоїв, втратила двох загиблих та одинадџятьох поранених ${ }^{24}$.

Наприкінці квітня українські війська відійшли на рубіж Пруси-Борщовичі. Проте Галицька армія контратакувала поляків, і 2 травня повернула втрачений раніше Миклашів, а 16 травня - Пруси. Зібравши резерви, поляки знову атакували по всьому фронту. Українські війська залишили Миклашів, потім відступали на Перемишляни, Бережани, Потутори, Підгайці. Мемуарист відзначив прикре явище: з'явилися у війську перші дезертири.

У червні відбулася реорганізація ГА. Так, 8 червня 5-та «батарея смерті» стала іменуватися 2-ю батареєю 10-го артилерійського полку ${ }^{25}$. Нові позиції артилеристи зайняли у Чорткова, звідки й розпочався останній наступ ГА. Спочатку він розвивався вдало, і українське військо наблизилося до Тернополя. Проте не вистачало озброєння та набоїв. «Знову будемо гнати ворога, і то його власною зброєю. Бо в нас своєї немає. Що здобудемо тим і воюємо» ${ }^{26}$.

у боях за Тернопіль батарея підтвердила свою назву «батарея смерті», під ворожим вогнем артилеристи виїхали на відкриті позиції та розстріляли ворожу піхоту. Тернопіль здобуто Галицькою армією. І у війську, і серед населення запанував оптимістичний настрій. «В кожному зайнятому селі все чоловіче населення вступало у наші ряди» ${ }^{27}$. Однак, 28 червня 1919 р. польська армія Ю. Галлера перейшла у загальний наступ. Українське військо не мало боєзапасів. Автор спогадів відзначив, що в боях за Золочів, дуже вдало діяли польські бронеавтомобілі. Втримати позиції не вдалося, проте артилеристи 3 надією дивилися у майбутнє. «Це був останній великий бій нашої армії на Галицькій землі. Тут вирішилась доля нашої армії, якій призначено перейти Збруч з політичним гаслом: через Київ - на Львів! ${ }^{28}$.

В ніч на 16 липня 1919 р. «батарея смерті», з іншими частинами Галицької армії, перейшла р. Збруч й об'єдналася 3 військом Директорії УНР. «Запалена ідеєю свободи молодь з Галичини і молодь з великих просторів Наддніпрянської України - разом ішла до волі і незалежности. Тоді ніхто навіть не думав про можливість невдачі ${ }^{29}$.

На початку серпня розпочався наступ обєднаних українських армій на Київ. «Батарея смерті» мала 4 гармати, 2 кулемети і налічувала 124 військових і 19 коней. Артилеристи

\footnotetext{
${ }^{23}$ Ibid. C. 40.

${ }^{24}$ Ibid. C. 53.

${ }^{25}$ Ibid. C. 68.

${ }^{26}$ Ibid. C. 71.

${ }^{27}$ Ibid. C. 76.

${ }^{28}$ Ibid. C. 84.

${ }^{29}$ Ibid. C. 85.
} 
рушили на Татаринку, Людвиківку й Охримівку. Мемуарист із «практичних» міркувань доводив ідею соборності України. «Не було чим запалити лампи увечері. Тож бачили ми, що не обійтись Україні без Борислава, переконались, що треба об'єднати всі українські території, щоб Україна стала самовистачальною державою» ${ }^{30}$ Помітив В. Галан і негативне явище: місцеві селяни скаржилися на більшовиків, проте у селах чимало молоді призовного віку, й усі сидять по домівках.

У війську, що наступало, відчувалася нестача зброї. 3 цього приводу очільник армії УНР С.Петлюра звернувся до українського селянства. «Знаю, що в кожному селі зараз знайдуться кулемети, в кожній хаті - рушниця та набої, і тому, як Головний Отаман, я вимагаю від Вас, селяни, допомогти мені в справі негайного забезпечення зброєю наших славних лицарів-козаків» ${ }^{31}$.

Мемуарист, розповідаючи про здобуття українським військом Вінниці, згадував, що із місцевої тюрми врятовано 110 в'язнів, яких не встигли стратити більшовики. Проте схоплених працівників радянської «надзвичайки», за вироком польового суду, розстріляно. Чимало вінничан із радістю зустріло прихід української армії ${ }^{32}$ Серед білышовиків, які відступали на Київ, поширились чутки, що проти них воюють «англійці».

у бою під Калинівкою «батареї смерті» довелося мати справу з українцямибільшовиками - тут оборону тримала радянська Таращанська дивізія. Після здобуття Бердичева, артилеристи наблизилися до містечка Ходорків, напередодні зайнятого повстанським загоном. «Повстанці у високих шапках тримали в руках транспаранти 3 написом: Вітаємо братів-галичан!» ${ }^{33}$ Нарешті, батарея 30 серпня зупинилася на р. Ірпінь під Києвом. А 31 серпня, коли українське військо увійшло до столиці, 10-й гарматний полк одержав наказ виступити на Гостоміль. Отже, В. Галану не довелося побувати в Києві, і він не був свідком «київської катастрофи», коли під тиском Добровольчої армії, галицьке командування залишило українську столицю. Він лише відзначив, що «несподіваний відступ з Києва спричинив хвилеве замішання в частинах УГА» ${ }^{34}$.

На початку вересня артилеристи Галана воювала з більшовиками в прип'ятських болотах. 4 вересня «батарея смерті» вступила до села Бузової. «Перш за все треба було похоронити гармаша Івана Зданіка, тіло якого лежало у шкільній залі. Діти прибрали його квітами. Теслі збили дубову труну і хрест з написом: "В боротьбі за Украіну віддав своє життя пушкар 2-ої батерії 10-го артилерійського полку УГА Іван Зданік з Озірної”... За довгих шість років війни прийшлося мені бачити багато могил, алі ні одна 3 них не вбилась мені в пам'ять так глибоко, як могила гармаша Зданіка» ${ }^{35}$.

Потім українські війська відійшли в район Бердичева. Мемуарист захворів на тиф і одужав 9 жовтня, після цього він з батареєю вирушив на новий фронт, проти військ генерала А.Денікіна. Проте, 6листопада 1919 р. укладено сепаратну угоду між командуванням Добровольчої армії та ГА про входження останньої до складу збройних сил

\footnotetext{
${ }^{30}$ Ibid. C. $87-88$.

${ }^{31}$ Петлюра С.В. До трудового селянства // Петлюра С.В. Статті. Київ: Дніпро, 1993. С. 179.

${ }^{32}$ Галан В. Вказ. праця. С. 90-91.

${ }^{33}$ Ibid. C. 99.

${ }^{34}$ Ibid. C. 104.

${ }^{35}$ Ibid. C. 106.
} 
А. Денікіна. Відтепер змінено і назву - на Українську Галицьку Армію (УГА). Володимир Галан, аналізуючи у мемуарах ті події, вказував, що не можна виправдати укладання угод із ворогом ніякими скрутними обставинами. Причиною переходу Галицької армії у стан Денікіна, на його думку, стало те, що не було єдності серед політичних еліт ЗУНР та УНР. «Фактично були дві армії з двома командуваннями і двома політичними проводами, не тільки не скоординованими, але й взаємносуперницькими» ${ }^{36}$. Передаючи настрої війська, В. Галан, писав, що серед особового складу «насправді ніхто не знав, що сталось, на яких умовах підписано той договір. Ми відчували, що сталося щось недобре» ${ }^{37}$. У складі вже Добровольчої армії, під тиском більшовиків, довелося відступати на Тульчин, Ободівку, Чечельник, Балту й аж до села Оленівка. І3-за епідемії тифу, артилерійський підрозділ став небоєздатним. «Був це радше польовий шпиталь, бо тих хворих ми возили з собою 3 місця на місце, а здорові гармаші виконували при них службу санітарів» ${ }^{38}$.

Мемуарист відзначав, що союз із Денікіним викликав невдоволення серед частини командування УГА. Розроблявся план, щоб відірвати армію від денікінців, перейти на південь у район Балти, там відпочити, реорганізуватися, провести набір новобранців і доповнити частини полоненими галичанами, що поверталися з Італії. Денікінці, які вже відступали під тиском радянських військ, навряд чи змогли перешкодити передислокації українських військ. «Наші обрахунки були такі: стан Галицької Армії можна піднести до бойового стану 60 000. Полонених в Італії начислювано на 100 000. Частини Дієвої Армії Петлюри становили 20 000. Разом 180000 старшин і вояків» ${ }^{39}$.

Однак військові реалії були зовсім несприятливі. Як представник 10-го гарматного полку, В. Галан виїхав 23 січня 1920 р. із села Оленівки до Кодими, в штаб УГА, на нараду щодо їі подальшого становища. «Здавалось, усі ми були переконані, що для фізичного рятунку Галицької Армії єдиним виходом було перемир'я з большевиками» ${ }^{40}$. На станції Кодима, 25 січня 1920 р. відбулася зустріч з командувачем УГА генерал-хорунжим О. Микиткою, який запропонував не укладати союз із більшовиками, а прориватися в район Одеси і звідти домовлятися про евакуацію армії через Румунію. Але більшовики стрімко наближалися, і 6-го лютого на нараді представників УГА у Чечельнику прийнято рішення розпочати переговори з радянським командуванням про спільні бойові діі ${ }^{41}$.

Відтепер військову службу В. Галан продовжив у складі ЧУГА (Червоної Української Галицької Армії). Тут він зіткнувся з реаліями більшовицького війська - комісарами. «До мене не раз підходили полковий політрук Кипріян (син священика, який вважав Христа за першого комуніста) та інші “політики”, намовляючи, щоб я також став політичним робітником, бо “гармаші мене поважають, і це помогло б партії. Моя відповідь була: я фронтовий старшина, про комунізм нічого не знаю і хочу задержати команду батерії так, щоб привести моїх гармашів в Галичину до їхніх батьків. Мене лишили в спокої» ${ }^{42}$. «Батарея смерті» одержала наказ рухатись на Браїлів, Літин у напрямі польського фронту.

\footnotetext{
${ }^{36}$ Ibid. C. 214.

${ }^{37}$ Ibid. C. 111.

${ }^{38}$ Ibid. C. 116.

${ }^{39}$ Ibid. C. 122.

${ }^{40}$ Ibid. C. 127.

${ }^{41}$ Ibid. C. 128.

${ }^{42}$ Ibid. C. 130.
} 
Проте, повоювати проти поляків довелося недовго. «Увечері 19 квітня, коли батерія вернулась на місце постою, мене покликали до Команди і заявили, що згідно з наказом бригади полк виступає проти большевиків, злучується з армією УНР і спільно з нею йде на Київ» ${ }^{43}$. Проте цей наказ виконати не вдалося, адже полк оточили та роззброїли поляки. Надамо слово мемуаристу: «Закінчення трагедії Галицької Армії прийшло в селі Дяківці 23 квітня 1920 року... В очах гармашів і стрільців відбивалась внутрішня боротьба і - жаль за втраченою волею і державою. Тоді всі зрозуміли воєнну засаду кожної армії - знищити ворога, і це робили послідовно й грунтовно поляки... Бойові старшини і стрільці відчували біль і страшний жаль до свого політичного проводу, який залишив їх напризволяще» ${ }^{4}$. Через деякий час спочатку стрільці, а потім і офіцери поступово залишили табір для полонених, частина з них вступила до армії УНР. Володимир Галан вирішив повернутися на батьківщину. Але побоюючись арешту польською владою, він нелегально перейшов кордон Чехословаччини.

Передаючи свої враження, мемуарист писав, що Чехословаччина стала рятівним притулком для багатьох тисяч української молоді та військових. «Восени 1920 р. українське життя в Празі кипіло... Була велика академічна громада студентів 3 відділів медицини, інженерії, торговельного факультету. Студенти поділились на два табори, - колишніх військовиків і тих, які цілу війну пересиділи в запіллі, а тепер виступали як всезнайки: "а ми вам казали”. До Праги перенесено з Відня Український Вільний Університет, в Подєбрадах створено Господарську Академію та Педагогічний Інститут. Чеський уряд ставився до нас дуже прихильно - давав стипендії, в університеті звільняли українців від оплат» ${ }^{45}$. Провчившись два роки у Празі, В. Галан вирішив переїхати до США. «Залишаючи європейський континент, я попрощався 3 товаришами зброї, а 22 грудня 1922 р. прибув до брата Михайла в Ню Йорк. Відтоді почався новий етап мого життя у вільній Америці» ${ }^{46}$ Мемуариста очікувала плідна громадська діяльність вже у середовищі української діаспори.

Таким чином, проведене дослідження демонструє важливість вивчення мемуарної літератури доби Української революції. Спогади В. Галана є важливим джерелом з історії УГА, на прикладі бойового шляху окремої артилерійської батареї, висвітлено визвольну боротьбу за українську державність по обидва береги Збручу протягом 1918-1920 рр. Активне залучення науковцями спогадів учасників тих подій, сприятиме формуванню максимально об’єктиної картини перебігу революційних процесів в Україні 1917-1921 рр.

Vladyslav Parkhomenko

\section{Memoirs of V. Galan as a Source on the History of the Galician Army}

Abstract: The article is devoted to the analysis of the memoirs of Vladimir Galan (18931978) as a source on the history of the Galician army in 1918-1920, its participation in the liberation struggle and the reasons for the failures. The formation and participation of the

\footnotetext{
${ }^{43}$ Ibid. C. 132.

${ }^{44}$ Ibid. C. 134.

${ }^{45}$ Ibid. C. 138.

${ }^{46}$ Ibid. C. 139.
} 
Galician army artillery in the hostilities of 1918-1920 is considered.

Attention is drawn to the personal context of the formation of the memoirs about the events of the Ukrainian revolution, personal motivation to write memoirs.

Military memoirs in fact often is the only source for the history of certain military units, conducting combat operations and their direct participants.

Considered is the degree of understanding in the memoirs transformational processes of the Ukrainian revolution under the influence of domestic- and foreign-policy situation during of 1917-1921.

Memoirs convey the mood of the individuals who left their memories to us. Thanks to them, you can see the versatility of the mentality of the society that fell into the whirlpool of turbulent political events.

It is noted that the active use of memoirs will contribute to a more detailed study of the events of the Ukrainian revolution of 1917-1921 by modern historical science.

Keywords: memoirs, liberation movement, nation-building, WUPR (West Ukrainian People Republic), Galician army, Ukrainian revolution of 1917-1921 